\title{
Characterisation of the magmatic signature in gas emissions from Turrialba Volcano, Costa Rica
}

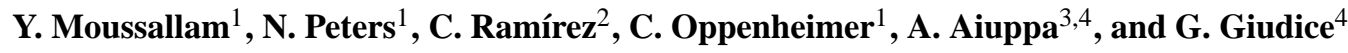 \\ ${ }^{1}$ Department of Geography, University of Cambridge, Downing Place, Cambridge, CB2 3EN, UK \\ ${ }^{2}$ Red Sismológica Nacional, University of Costa Rica (UCR), San Jose, Costa Rica \\ ${ }^{3}$ Dipartimento DiSTeM, Università di Palermo, Via archirafi 36, 90146, Palermo, Italy \\ ${ }^{4}$ Instituto Nazionale di Geofisica e Vulcanologia, Sezione di Palermo Via La Malfa, 153, 90146, Palermo, Italy \\ Correspondence to: Y. Moussallam (yves.moussallam@cnrs-orleans.fr)
}

Received: 15 July 2014 - Published in Solid Earth Discuss.: 8 August 2014

Revised: 10 November 2014 - Accepted: 11 November 2014 - Published: 20 December 2014

\begin{abstract}
The equilibrium composition of volcanic gases with their magma is often overprinted by interaction with a shallow hydrothermal system. Identifying the magmatic signature of volcanic gases is critical to relate their composition to properties of the magma (temperature, $f \mathrm{O}_{2}$, gas-melt segregation depth). We report measurements of the chemical composition and flux of the major gas species emitted from Turrialba Volcano during March 2013. Measurements were made of two vents in the summit region, one of which opened in 2010 and the other in 2012. We determined an average $\mathrm{SO}_{2}$ flux of $5.2 \pm 1.9 \mathrm{~kg} \mathrm{~s}^{-1}$ using scanning ultraviolet spectroscopy, and molar proportions of $\mathrm{H}_{2} \mathrm{O}, \mathrm{CO}_{2}, \mathrm{SO}_{2}$, $\mathrm{HCl}, \mathrm{CO}$ and $\mathrm{H}_{2}$ gases of 94.16, 4.03, 1.56, 0.23, 0.003 and $0.009 \%$ respectively by open-path Fourier transform infrared (FTIR) spectrometry and a multi-species gas-sensing system. Together, these data imply fluxes of $88,8,0.44,5 \times 10^{-3}$ and $1 \times 10^{-3} \mathrm{~kg} \mathrm{~s}^{-1}$ for $\mathrm{H}_{2} \mathrm{O}, \mathrm{CO}_{2}, \mathrm{HCl}, \mathrm{CO}$ and $\mathrm{H}_{2}$ respectively. Although $\mathrm{H}_{2} \mathrm{~S}$ was detected, its concentration could not be resolved. HF was not detected. The chemical signature of the gas from both vents was found to be broadly similar. Following the opening of the 2010 and 2012 vents we found limited to negligible interaction of the magmatic gas with the hydrothermal system has occurred and the gas composition of the volcanic plume is broadly representative of equilibrium with the magma. The time evolution of the gas composition, the continuous emission of large quantities of $\mathrm{SO}_{2}$, and the physical evolution of the summit area with new vent openings and more frequent eruptions all point towards a continuous drying of the hydrothermal system at Turrialba's summit at an apparently increasing rate.
\end{abstract}

\section{Introduction}

Measurement of gas emissions from volcanoes in a state of unrest can provide valuable information regarding the evolution of the magmatic system and play a key role in eruption forecasting strategies (e.g. Merapi 2010 crisis; Surono et al., 2012). In recent years, tremendous progress in instrumentation has been made with the development of miniature UV spectrometers (e.g. Oppenheimer, 2010), open-path Fourier transform infrared (FTIR) spectroscopy (e.g. Horrocks et al., 2001) and multi-species gas-sensing systems (e.g. Aiuppa et al., 2006), making rapid measurement of all major gas species a relatively straightforward endeavour given favourable conditions.

Turrialba Volcano is located at the southern tip of the "Cordillera Central" (Fig. 1) a Holocene volcanic belt formed by the subduction of the Cocos Plate beneath the Caribbean Plate. Turrialba lies $35 \mathrm{~km}$ away from San José and $15 \mathrm{~km}$ away from Cartago, the first and second largest cities in Costa Rica. Since its last major eruption in 18841886 (Reagan et al., 2006), the volcano has been passively degassing via a rapidly changing fumarolic system (Vaselli et al., 2010). Three craters make up the summit area of Turrialba: the east crater, central crater and west crater. The fumarole activity is concentrated around the west crater in three main regions (Fig. 2): the northern fumarole field, the 2010 vent and the 2012 vent. At the time of our fieldwork in March 2013, gas emitted from the 2012 vent reached up to $700-800^{\circ} \mathrm{C}$, while gas emitted from the 2010 vent was up to $400^{\circ} \mathrm{C}$. These temperatures were measured using a hand-held thermal camera (at a range of $\sim 350$ and $\sim 20 \mathrm{~m}$ 


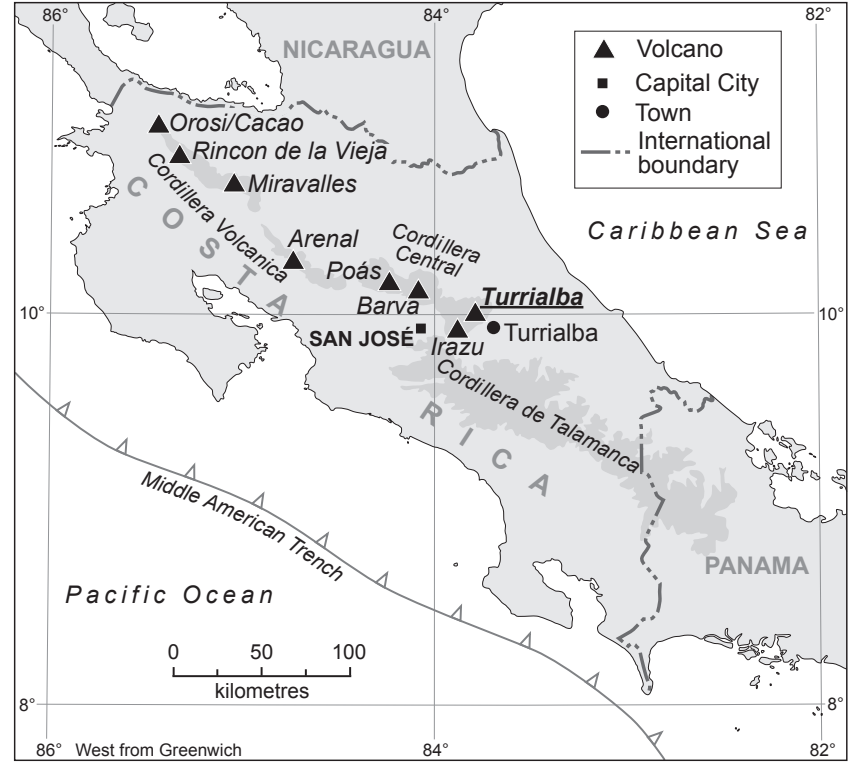

Figure 1. Location map showing Turrialba Volcano at the southern tip of the Cordillera Central volcanic belt.

respectively) and were not corrected for atmospheric transmission. These thus indicate minimum estimates of the true gas temperature.

Following an episode of intense fumarolic activity in 2008 and persistent acid rain ever since, the vegetation within a 1$2 \mathrm{~km}$ radius of the summit has been strongly affected (Martini et al., 2010). Livestock have also been affected and a large portion of the local population has left the area after suffering economic losses or health issues (Martini et al., 2010). On 5 January 2010, a small phreatic eruption opened a new vent (the 2010 vent) and resulted in ash falls reaching the suburbs of San José (OVSICORI 2010; González et al., 2014). On 12 January 2012, a new vent opened on the southeast flank of the west crater and ash fell as far as Tres Rios $(27 \mathrm{~km}$ SW from the vent) (OVSICORI 2012; González et al., 2014). The national park of Turrialba closed following this event and has remained so since. On 21 May 2013, an eruption from the 2010 and 2012 vents resulted in ash falls more than $40 \mathrm{~km}$ away (OVSICORI 2013; Red Sismologica Nacional, 2013). The recent change in the style of degassing together with the increasing frequency of minor ash eruptions underlines the importance of investigation of the composition of the gas emissions in order to understand the evolution of the magma-hydrothermal system.

Here we report measurements of the gas emissions from the 2010 and 2012 vents at Turrialba Volcano using (i) scanning ultraviolet differential optical absorption spectroscopy (DOAS), (ii) open-path FTIR spectroscopy and (iii) multispecies gas-sensing systems ("multi-gas"). Reported measurements of the gas chemistry and flux at Turrialba have been few and sporadic. Vaselli et al. (2010) characterised the

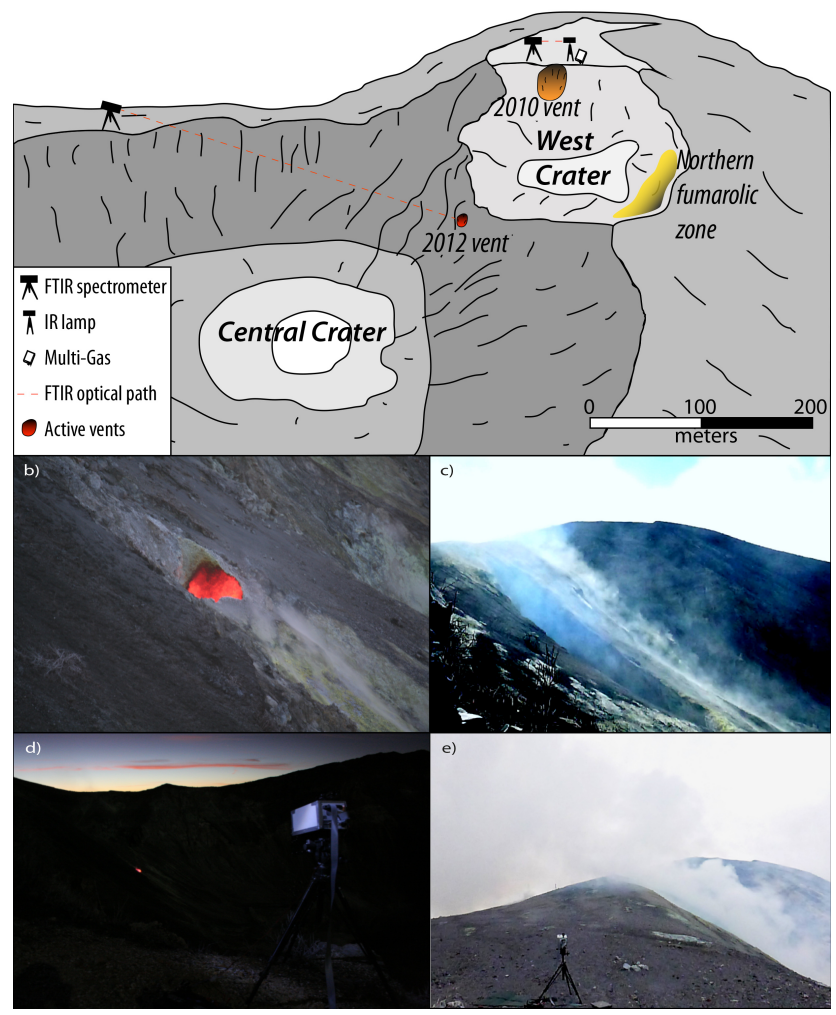

Figure 2. (a) Summit area of Turrialba looking due south, showing (not drawn to scale) the location of the three main vents and fumarolic fields together with the various locations of the FTIR spectrometer and "multi-gas" instrument. (b) Close-up view of the 2012 vent at sunset. (c) Close-up view of the 2010 vent. (d) Picture of the instrumental setup on 25 March 2013 with the FTIR spectrometer pointing at the 2012 vent (courtesy of Kayla Iacovino). (e) Picture of the instrumental setup on 26 March 2013 with the FTIR spectrometer pointing at an infrared lamp across the wind-blown mixed plume directly south of the 2010 vent.

change in gas composition of fumaroles from the hydrothermal system from 1998 to 2008, while Martini et al. (2010) and Campion et al. (2012) reported measurement of the $\mathrm{SO}_{2}$ flux from 2002 to 2008 and 2009 to 2011 respectively. The opening of the 2010 vents and associated increase in $\mathrm{SO}_{2}$ flux was interpreted as the beginning of open-vent degassing (Campion et al., 2012). The present investigation spans a period from 22 to 26 March 2013. The aim of this investigation is to provide measurements of the magmatic gases emitted from Turrialba at an early stage in its new open-vent-style activity in order to provide a reference point for future investigations of the gas emissions from this potentially hazardous volcano. Such studies, especially if they are repeated, are important in identifying the evolution of volcanic unrest, particularly in the case of reactivation of long-dormant volcanoes. 


\section{Methods}

\subsection{Scanning DOAS}

Horizontal scans transecting the plume just above the crater were made from a site $2 \mathrm{~km}$ away from the summit (Fig. S1a in the Supplement). The plume rose vertically to approximately $400 \mathrm{~m}$ before being drifting horizontally with the wind, such that scans always cleared the plume on both sides (Fig. S1b and S1c). Data acquisition was paused whenever cloud formed within the field of view. The acquisition of data and subsequent retrieval of $\mathrm{SO}_{2}$ flux values followed the standard DOAS methodology (Galle et al., 2003; Platt and Stutz, 2008) using a fitting window of $315-325 \mathrm{~nm}$. Scans were taken by mounting a telescope (coupled to the spectrometer by a fibre) on a small, custom-made, USB-powered scanning stage. The spectrometer recorded continuously as the stage was rotated back and forth and angles were assigned to each spectrum in post-processing using their time stamps (recorded with millisecond precision) and an angle-versustime $\log$ file created by the scanning software (Avoscan, 2013). Scans were made at a distance of $2.1 \mathrm{~km}$ from the plume, with an inclination angle of $20^{\circ}$ above horizontal. The scanning stage was in motion continuously, with spectra being recorded such that each spectrum is the average over $0.1^{\circ}$ of scan. The plume conditions varied slightly over the period of measurement; however, it was typically $5-8^{\circ}$ in width as viewed from the scan site (183-293 m). Each scan therefore contained between 50 and 80 in-plume measurements. Figure S1c shows a representative scan from 23 March. As shown in Fig. S1c, the scans covered the entire plume and included clear-sky backgrounds on each side. The plume transparency, estimated as the ratio of signals at about $360 \mathrm{~nm}$ registered inside and outside the plume typically varied between 0.9 and 0.8 ( 0 representing an entirely opaque plume and 1 an entirely transparent plume) (Fig. S1d).

Rise speeds for the plume were estimated using a dual wide field of view (DW-FOV) spectrometer system similar to that described by Boichu et al. (2010) (Fig. S1e). This was operated alongside the scanning unit, and data from the two telescopes were cross-correlated using a window length of $300 \mathrm{~s}$ to determine the rise speed. We used the solar spectrum measured by Chance and Kurucz (2010) and $\mathrm{SO}_{2}$ and $\mathrm{O}_{3}$ reference spectra measured by Vandaele et al. (1994) and Burrows et al. (1999) respectively. All DOAS retrievals were implemented using a combination of the DOASIS software (https://doasis.iup.uni-heidelberg.de) and scripts written by Vitchko Tsanev (http://www.geog.cam.ac. $\mathrm{uk} / \mathrm{research} / \mathrm{projects} /$ doasretrieval/).

The scanning stage uses a stepper motor with a $99: 1$ planetary gearbox, giving it an accuracy of $\pm 0: 01$. Note that errors due to crash-back in the gearbox are systematic for a single scan, and therefore do not affect the integrated column amount. The precision of the time stamps in the spectrum files (milliseconds) has a small effect on the accuracy of the angles. Using Eq. (1) and the standard error propagation equation the error in the angle $\left(\delta_{\theta_{\tau}}\right)$ of a spectrum recorded at time $\tau$ can be calculated by

$\delta_{\theta_{\tau}}=\left|\theta_{\tau}\right| \cdot \sqrt{\delta_{\theta}^{2}+\left(\left(\tau-\tau_{0}\right) \cdot \frac{\mathrm{d} \theta}{\mathrm{d} t}\right)^{2} \cdot\left(2 \delta_{\theta}^{2}+\frac{\delta_{\tau}^{2}}{\left(\tau-\tau_{0}\right)^{2}}\right)}$,

where $\delta_{\theta}=0.01^{\circ}$ is the uncertainty in the angle of the stepper motor and $\delta_{\tau}=0.001 \mathrm{~s}$ is the uncertainty in the capture time of the spectrum.

Error in the retrieved $\mathrm{SO}_{2}$ column amount is estimated by the DOASIS software by analysing the residual from the fitting of the reference and Ring spectra. Propagating these errors along with those in the angles through Eq. (2) gives the following as an estimate of the error in the flux $\left(\delta_{\Phi}\right)$ :

$\delta_{\Phi}^{2}=\Phi^{2}\left[\left(\frac{k v \delta_{\mathrm{ICA}}}{\Phi}\right)^{2}+\left(\frac{\delta_{\mathrm{v}}}{v}\right)^{2}\right]$,

where $\delta_{\mathrm{v}}=1 \mathrm{~m} \mathrm{~s}^{-1}$ is the uncertainty in the plume rise speed (corresponding to 1 standard deviation on measured rise speed) and $\delta_{\text {ICA }}$ is the error in the integrated column amount given by

$\delta_{\mathrm{ICA}}^{2}=\sum_{i=0}^{n-1} A_{i}^{2}\left[\left(\frac{\sqrt{\delta_{\theta_{i}^{2}}+\delta_{\theta_{i+1}^{2}}}}{\theta_{i+1}-\theta_{i}}\right)^{2}+\left(\frac{\sqrt{\delta_{A_{i}^{2}}+\delta_{A_{i+1}^{2}}}}{A_{i+1}-A_{i}}\right)^{2}\right]$.

\subsubsection{FTIR spectroscopy}

Open-path FTIR measurements were made on 25 and 26 March 2013. The spectrometer (MIDAC M4411-S) was equipped with a Stirling-cooled MCT detector and a 3 in. telescope. We collected interferograms with a nominal optical path difference (retardation) of $2.0 \mathrm{~cm}$, corresponding to a spectral resolution of $0.5 \mathrm{~cm}^{-1}$. On 25 March, the spectrometer was pointing directly at the 2012 vent, using it as the infrared radiation source (optical path length $\sim 350 \mathrm{~m}$ ). During acquisition, gases emitted from the 2012 vent were rising straight up at high velocity (observed with a thermal camera) such that volcanic gas plume was approximately $2 \mathrm{~m}$ thick. On 26 March a $15 \mathrm{~cm}$ diameter infrared lamp provided the source of radiation and was positioned $\sim 35 \mathrm{~m}$ from the spectrometer, both deployed on the southern edge of the western crater, directly south of the 2010 vent. Measurements were collected as the plume passed through the optical path. Interferograms were collected at $\sim 1 \mathrm{~Hz}$. Raw interferograms were inverse Fourier transformed to yield single-beam spectra using a Mertz phase correction and triangular apodisation. Column amounts of $\mathrm{H}_{2} \mathrm{O}, \mathrm{CO}_{2}, \mathrm{CO}, \mathrm{SO}_{2}$ and $\mathrm{HCl}$ were retrieved from their absorption fingerprint in single-beam spectra using a well-tested code (Burton et al., 2007, 2000; Horrocks et al., 2001) that simulates and fits atmospheric transmittance in discrete wavebands. Fitting parameters are given in Table 1. 
Table 1. Spectral micro-window and all other parameter used for fitting the target gas species.

\begin{tabular}{|c|c|c|c|c|c|c|c|c|c|c|c|c|}
\hline Day & $\begin{array}{l}\text { Target } \\
\text { gas }\end{array}$ & $\begin{array}{l}\text { Target } \\
\text { gas } \\
\text { spectral } \\
\text { window } \\
\left(\mathrm{cm}^{-1}\right)\end{array}$ & $\begin{array}{l}\text { Order of } \\
\text { background } \\
\text { polynomial }\end{array}$ & $\begin{array}{l}\text { Species } \\
\text { also } \\
\text { included } \\
\text { in the fit }\end{array}$ & $\begin{array}{l}\text { Field } \\
\text { view } \\
\text { (radiant) }\end{array}$ & $\begin{array}{l}\text { Reference } \\
\text { wave } \\
\text { number } \\
\left(\mathrm{cm}^{-1}\right)\end{array}$ & $\begin{array}{l}\text { Volcanic } \\
\text { gas } \\
\text { pressure } \\
(\mathrm{hPa})\end{array}$ & $\begin{array}{l}\text { Volcanic } \\
\text { gas } \\
\text { temperature } \\
(\mathrm{K})\end{array}$ & $\begin{array}{l}\text { Atmospheric } \\
\text { gas } \\
\text { temperature } \\
\text { (K) }\end{array}$ & $\begin{array}{l}\text { Volcanic } \\
\text { gas } \\
\text { path } \\
\text { length } \\
(\mathrm{km})\end{array}$ & $\begin{array}{l}\text { Atmospheric } \\
\text { path } \\
\text { length } \\
(\mathrm{km})\end{array}$ & Notes \\
\hline 25 March 2013 & $\begin{array}{l}\mathrm{SO}_{2} \\
\mathrm{CO}_{2} \\
\mathrm{H}_{2} \mathrm{O} \\
\mathrm{HCl}\end{array}$ & $\begin{array}{l}2440-2540 \\
2020-2100 \\
2020-2100 \\
2690-2830\end{array}$ & $\begin{array}{l}3 \\
2 \\
2 \\
3\end{array}$ & $\begin{array}{l}\mathrm{H}_{2} \mathrm{O}, \mathrm{CH}_{4}, \mathrm{~N}_{2} \mathrm{O} \\
\mathrm{H}_{2} \mathrm{O}, \mathrm{CO} \\
\mathrm{CO}, \mathrm{CO}_{2} \\
\mathrm{H}_{2} \mathrm{O}, \mathrm{CH}_{4}, \mathrm{~N}_{2} \mathrm{O}\end{array}$ & $\begin{array}{l}0.45 \\
0.61 \\
0.61 \\
0.42\end{array}$ & $\begin{array}{l}2490 \\
2060 \\
2060 \\
2750\end{array}$ & $\begin{array}{l}700 \text { (for } \\
\text { Turrialba } \\
\text { summit) }\end{array}$ & 450 & 295 & 0.002 & 0.35 & $\begin{array}{l}\text { FTIR to } \\
\text { small } \\
\text { incandescent } \\
2012 \text { vent }\end{array}$ \\
\hline 26 March 2013 & $\begin{array}{l}\mathrm{SO}_{2} \\
\mathrm{CO}_{2} \\
\mathrm{H}_{2} \mathrm{O} \\
\mathrm{CO} \\
\mathrm{HCl}\end{array}$ & $\begin{array}{l}2440-2540 \\
2020-2100 \\
2020-2100 \\
2020-2100 \\
2690-2830\end{array}$ & $\begin{array}{l}3 \\
2 \\
2 \\
2 \\
3\end{array}$ & $\begin{array}{l}\mathrm{H}_{2} \mathrm{O}, \mathrm{CH}_{4}, \mathrm{~N}_{2} \mathrm{O} \\
\mathrm{H}_{2} \mathrm{O}, \mathrm{CO} \\
\mathrm{CO}, \mathrm{CO}_{2} \\
\mathrm{H}_{2} \mathrm{O}, \mathrm{CO}_{2} \\
\mathrm{H}_{2} \mathrm{O}, \mathrm{CH}_{4}, \mathrm{~N}_{2} \mathrm{O}\end{array}$ & $\begin{array}{l}0.45 \\
0.61 \\
0.61 \\
0.47 \\
0.42\end{array}$ & $\begin{array}{l}2490 \\
2060 \\
2060 \\
2150 \\
2750\end{array}$ & $\begin{array}{l}700 \text { (for } \\
\text { Turrialba } \\
\text { summit) }\end{array}$ & 300 & 290 & 0.03 & 0.035 & $\begin{array}{l}\text { FTIR } \\
\text { to lamp } \\
\text { south } \\
\text { of } 2010 \\
\text { vent }\end{array}$ \\
\hline
\end{tabular}

\subsubsection{In situ gas measurements}

Electrochemical and non-dispersive infrared (NDIR) sensors ("multi-gas") measurements were performed on 24,25 and $26 \mathrm{March}$ at a sample rate of $0.5 \mathrm{~Hz}$. The instrument was deployed on the southern edge of the western crater, directly south of the 2010 vent at an altitude of $3280 \mathrm{~m}$ a.s.l. On 25 March the instrument was located a few metres away from the IR lamp. The multi-gas instrument incorporated $\mathrm{H}_{2}, \mathrm{H}_{2} \mathrm{~S}$, $\mathrm{CO}$ and $\mathrm{SO}_{2}$ electrochemical sensors; an NDIR sensor for $\mathrm{CO}_{2}$; and a sensor for temperature and humidity measurements. In this type of instrument, the sampled gas is circulated via a miniature $12 \mathrm{~V}$ rotary pump through the sensors (e.g. Aiuppa et al., 2011). The NDIR $\mathrm{CO}_{2}$ sensor (model Gascard II) is calibrated for 0-3000 ppmv with an accuracy $\pm 2 \%$ and a resolution of $0.8 \mathrm{ppmv}$. The electrochemical sensor for $\mathrm{SO}_{2}$ (City Technology, sensor type 3ST/F) has a calibration range of $0-200 \mathrm{ppmv}$, an accuracy of $\pm 2 \%$, a repeatability of $1 \%$ and a resolution of 0.5 ppmv. The electrochemical sensor for $\mathrm{H}_{2}$ (City Technology, sensor type 3HYT) has a calibration range of $0-500 \mathrm{ppmv}$, an accuracy of $\pm 5 \%$ a repeatability of $2 \%$ and a resolution of 2 ppmv. In addition to the gas sensors, temperature and relative humidity sensors (Galltec) are mounted in the instrument, providing a measuring range of $0-100 \% \mathrm{RH}$ and an accuracy of $\pm 2 \%$. All sensors were housed inside a weatherproof box, with the ambient air sampled via Teflon tubing connected to a HEPA filter fed through an inlet in the box. The sampled gas was dispersed via an outlet similarly fed through a hole in the case. An on-board data-logger card in the "multi-gas" instrument captured measurements at a rate of $0.5 \mathrm{~Hz}$. All sensors were calibrated in the laboratory on 5 February 2013 with target gases of known concentration. The response time of all sensors was rapid, but the $\mathrm{H}_{2}, \mathrm{H}_{2} \mathrm{~S}$ and $\mathrm{CO}$ sensors were found to respond more slowly than $\mathrm{SO}_{2}$ and $\mathrm{CO}_{2}$ sensors (see Fig. S2). The differences in response time for the different sensors were corrected by finding the lag times from correlation analysis of the various time series.

\section{Results}

\section{1 $\mathrm{SO}_{2}$ flux}

Emission rates of $\mathrm{SO}_{2}$ are shown in Fig. 3 as flux in kilograms per second and tonnes per day for measurements made on 22, 23 and 25 March 2013. We report only fluxes obtained during cloud-free periods where the plume was well defined and was cleared by the scan on both sides. The mean and maximum values of $\mathrm{SO}_{2}$ column amount within the plume where (all values in ppmm) on 22 March: mean $=2012$, $\mathrm{SD}=615, \max =3553$; on 23 March: mean $=1885, \mathrm{SD}=621$, $\max =3687$; and on 25 March: mean $=1200, \mathrm{SD}=586$, $\max =2548$. Column amount measurements were associated with an error (based on standard deviation of retrieved column amount outside the plume) of \pm 59 on 22 March, \pm 61 on 23 March and \pm 71 on 25 March. The average $\mathrm{SO}_{2}$ emission rate on 22 March, 23 March and 25 March is $8.4 \pm$ $1.3 \mathrm{~kg} \mathrm{~s}^{-1}$ (equivalent to $727 \pm 113 \mathrm{td}^{-1}$ ), $4.7 \pm 1.4 \mathrm{~kg} \mathrm{~s}^{-1}$ (equivalent to $404 \pm 118 \mathrm{td}^{-1}$ ) and $4.3 \pm 1.0 \mathrm{~kg} \mathrm{~s}^{-1}$ (equivalent to $376 \pm 90 \mathrm{t} \mathrm{d}^{-1}$ ) respectively, giving a 3 -day average of $5.2 \pm 1.9 \mathrm{~kg} \mathrm{~s}^{-1}$ (equivalent to $446 \pm 162 \mathrm{td}^{-1}$ ). Figure 3 shows that significant (greater than 3 standard deviations) variation in $\mathrm{SO}_{2}$ flux occur at a timescale of hours to days.

\subsection{Chemistry}

\subsubsection{Multi-gas}

We obtained $6.8 \mathrm{~h}$ of good-quality observations of the 2010 vent chemistry using the multi-gas instrument. $\mathrm{H}_{2}$ and $\mathrm{H}_{2} \mathrm{~S}$ sensors were found to be sensitive to changes in temperature, drifting strongly at temperature above $26^{\circ} \mathrm{C}$. We therefore only report $2.1 \mathrm{~h}$ of $\mathrm{H}_{2}$ measurements which were acquired at sampled air temperatures between 20 and $25^{\circ} \mathrm{C}$, close to the laboratory calibration temperature. The $\mathrm{H}_{2} \mathrm{~S}$ signal was strongly dominated by its $10-15 \%$ cross-correlation with $\mathrm{SO}_{2}$ and after correction $\mathrm{H}_{2} \mathrm{~S}$ was not detected. $\mathrm{CO}$ was likewise not detected by the electrochemical sensor. Figure 4 shows four scatter plots for continuous measurements acquired on 24, 25 and 26 March. Scatter plots for the $\mathrm{CO}_{2}$ and 

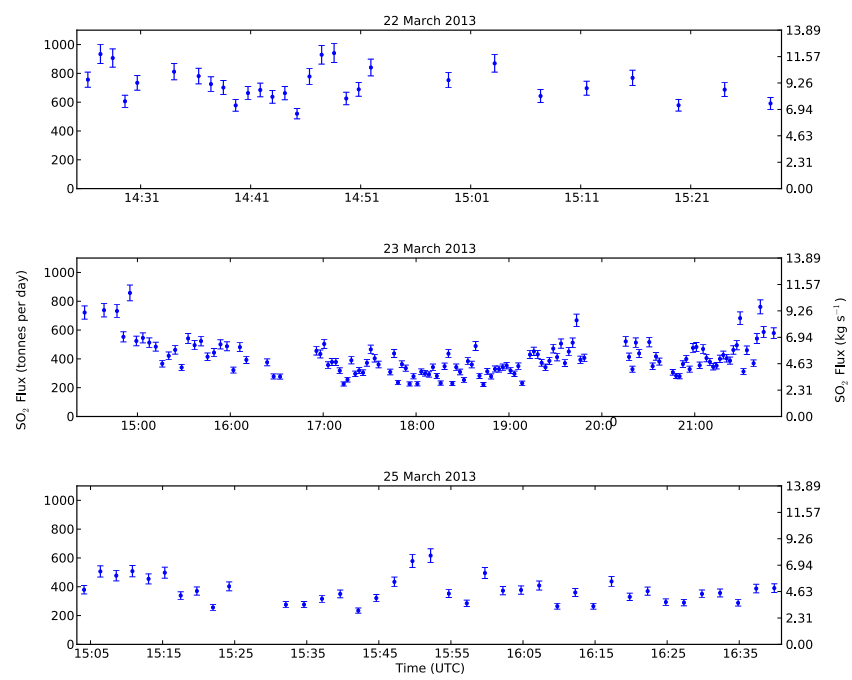

Figure 3. $\mathrm{SO}_{2}$ fluxes shown in $\mathrm{td}^{-1}$ and $\mathrm{kg} \mathrm{s}^{-1}$ for 3 days of observations using DOAS horizontal scanning directly above the summit from a fixed observation point $2.0 \mathrm{~km}$ away (horizontal distance) from the summit. Only cloud-free periods with scans clearing the plume on both sides are reported.

$\mathrm{SO}_{2}$ measurements yield $\mathrm{CO}_{2} / \mathrm{SO}_{2}$ molar ratios varying between 1.66 and 1.79 (Fig. 4a, b, c), with a weighted average of 1.76. The $\mathrm{H}_{2}$ and $\mathrm{SO}_{2}$ scatter plot (Fig. 4d) measurements yield a $\mathrm{H}_{2} / \mathrm{SO}_{2}$ molar ratio of 0.006 . It is to be noted that the hydrogen level above atmospheric background is very weak and hence has a large associated error. The significant scattering seen in the multi-gas data is not solely a reflection of the measurement error but also reflects the variability of the gas sampled. Indeed while the largest contributor to the analysed gas plume appeared to be the 2010 vent, contributions from the 2012 vent, nearby low-temperature fumaroles and occasionally the northern fumarolic field are likely. The reported multi-gas measurements are therefore an approximation of the bulk plume composition and not strictly a reflection of the gas chemistry of the 2010 vent.

\subsubsection{FTIR}

A total of 2162 spectra were collected on 26 March and analysed for $\mathrm{H}_{2} \mathrm{O}, \mathrm{CO}_{2}, \mathrm{SO}_{2}, \mathrm{CO}, \mathrm{HCl}, \mathrm{HF}, \mathrm{CH}_{4}$ and $\mathrm{N}_{2} \mathrm{O}$. Figure 5a-d show the scatter plots for $\mathrm{CO}, \mathrm{CO}_{2}, \mathrm{H}_{2} \mathrm{O}$ and $\mathrm{HCl}$ column amount plotted against $\mathrm{SO}_{2}$. A total of 3983 spectra for the 2012 vent plume were collected on 25 March and analysed for the same species. Figure $5 \mathrm{e}$ and $\mathrm{f}$ show the column amount scatter plots for $\mathrm{H}_{2} \mathrm{O}$ and $\mathrm{HCl}$ plotted against $\mathrm{SO}_{2}$. The scatter is much greater in measurements of the 2012 vent due to the passive sensing field setup (short path length of gas relative to total path length and low infrared source strength) and contamination of the absorption signal by IR radiation from the hot gases. The latter issue made it particularly difficult to make useful measurements, and all retrievals showing unreasonable amounts (e.g. negative) of
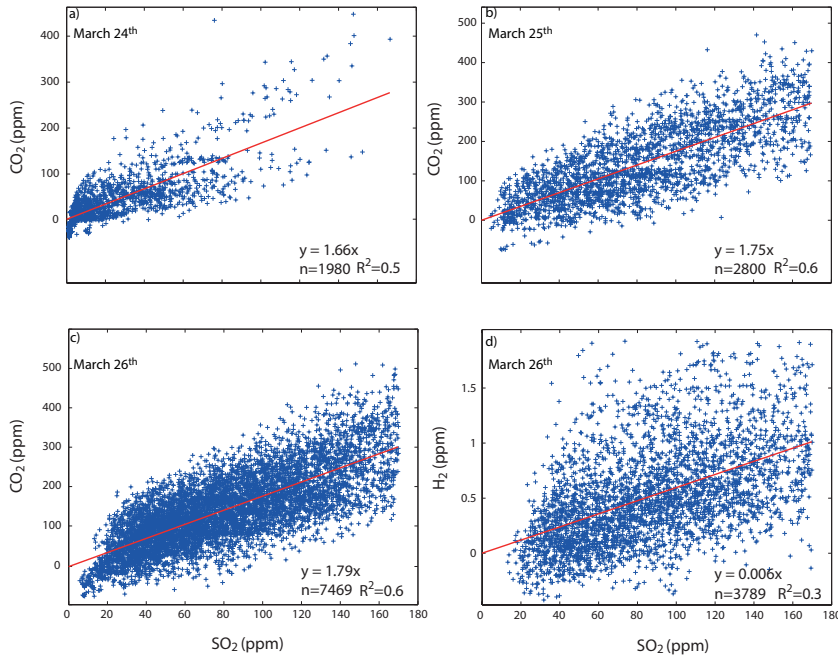

Figure 4. $\mathrm{CO}_{2}$ vs. $\mathrm{SO}_{2}$ and $\mathrm{H}_{2}$ vs. $\mathrm{SO}_{2}$ scatter plots from 3 days of sampling of the Turrialba mixed plume, directly south of the 2010 vent using a multi-species gas-sensing system. (a) 17:52 to 18:58 UTC, 24 March 2013. (b) 20:24 to 21:57 UTC, 25 March 2013. (c) 22:05 UTC, 25 March 2013, to 02:14 UTC, 26 March 2013. (d) 00:10 to 02:14 UTC, 26 March 2013. Regression lines are shown in red and corresponding parameters are displayed in the lower right corner of each plot.

$\mathrm{HCl}$ and $\mathrm{H}_{2} \mathrm{O}$ were dismissed. $\mathrm{CO}_{2}$ measurements obtained with this setup were too noisy for an accurate $\mathrm{CO}_{2} / \mathrm{SO}_{2}$ ratio to be obtained. Column amounts of $\mathrm{CH}_{4}$ and $\mathrm{N}_{2} \mathrm{O}$ were stable throughout the measurement period, indicating that these species were present in the ambient atmosphere but were not detected in the plume. HF was not detected in any of the spectra and $\mathrm{CO}$ was below the detection limit for measurements of the 2012 vent emissions, possibly due to the short path length of gas relative to the total path length but most probably due to the low energy from the source. The $\mathrm{CO}_{2}$ intercept of $2.05 \times 10^{19}$ molecules $\mathrm{cm}^{-2}$, from Fig. $5 \mathrm{~b}$, corresponds to an atmospheric mixing ratio of $336 \mathrm{ppmv}$ over a $35 \mathrm{~m}$ path length (based on an ambient air temperature of $290 \mathrm{~K}$ and a pressure of $700 \mathrm{hPa}$ ) and agrees reasonably well with the expected ambient abundance of $\mathrm{CO}_{2}$.

By converting the molar ratios of volcanic gas species illustrated in Fig. 4 and 5 to mass ratios and multiplying by the average $\mathrm{SO}_{2}$ flux obtained from scanning DOAS, we can estimate emission rates of each individual gas from Turrialba. We obtained fluxes of $88,8,0.44,5 \times 10^{-3}$ and $1 \times 10^{-3} \mathrm{~kg} \mathrm{~s}^{-1}$ for $\mathrm{H}_{2} \mathrm{O}, \mathrm{CO}_{2}, \mathrm{HCl}, \mathrm{CO}$ and $\mathrm{H}_{2}$ respectively (Table 2) with associated error of $\pm 32.3,3.4,0.16,0.0017$ and $4 \times 10^{-4} \mathrm{~kg} \mathrm{~s}^{-1}$ for $\mathrm{H}_{2} \mathrm{O}, \mathrm{CO}_{2}, \mathrm{HCl}, \mathrm{CO}$ and $\mathrm{H}_{2}$ respectively (based on error from $\mathrm{SO}_{2}$ flux measurement). 
Table 2. $\mathrm{X} / \mathrm{SO}_{2}$ molar and mass ratios measured by FTIR spectroscopy and multi-gas (for $\mathrm{H}_{2}$ ) and gas composition of the mixed plume. The inferred flux range of each species is based on an $\mathrm{SO}_{2}$ flux estimate of $210.7 \mathrm{td}^{-1}$. Errors are expressed as the standard error of the regression analysis and subsequent propagation.

\begin{tabular}{lcccccccc}
\hline Gas & $\begin{array}{c}\text { Mixed plume } \\
\text { molar ratio } \\
\left(\mathrm{X} / \mathrm{SO}_{2}\right)\end{array}$ & $\sigma$ & $\begin{array}{c}\text { Mixed plume } \\
\text { mass ratio } \\
\left(\mathrm{X} / \mathrm{SO}_{2}\right)\end{array}$ & $\sigma$ & $\begin{array}{c}\text { Mixed plume } \\
\text { composition } \\
(\mathrm{mol})\end{array}$ & $\sigma$ & $\begin{array}{c}\text { Inferred } \\
\text { flux } \\
\left(\mathrm{td}^{-1}\right)\end{array}$ & $\begin{array}{c}\text { Inferred } \\
\text { flux } \\
\left(\mathrm{kg} \mathrm{s}^{-1}\right)\end{array}$ \\
\hline $\mathrm{H}_{2} \mathrm{O}$ & 60.48 & 1.2 & 17.01 & 0.34 & 94.16 & 1.87 & 7585 & 88 \\
$\mathrm{CO}_{2}$ & 2.59 & 0.06 & 1.78 & 0.04 & 4.03 & 0.09 & 794 & 9 \\
$\mathrm{SO}_{2}$ & 1.00 & - & 1.00 & - & 1.56 & - & 446 & 5 \\
$\mathrm{HCl}$ & 0.15 & 0.001 & 0.09 & 0.0006 & 0.23 & 0.002 & 38 & 0.44 \\
$\mathrm{CO}$ & 0.0021 & 0.00003 & 0.0009 & 0.00001 & 0.003 & 0.00005 & 0.41 & 0.005 \\
$\mathrm{H}_{2}$ & 0.006 & 0.001 & 0.0002 & 0.00003 & 0.009 & 0.002 & 0.08 & 0.0010 \\
\hline
\end{tabular}
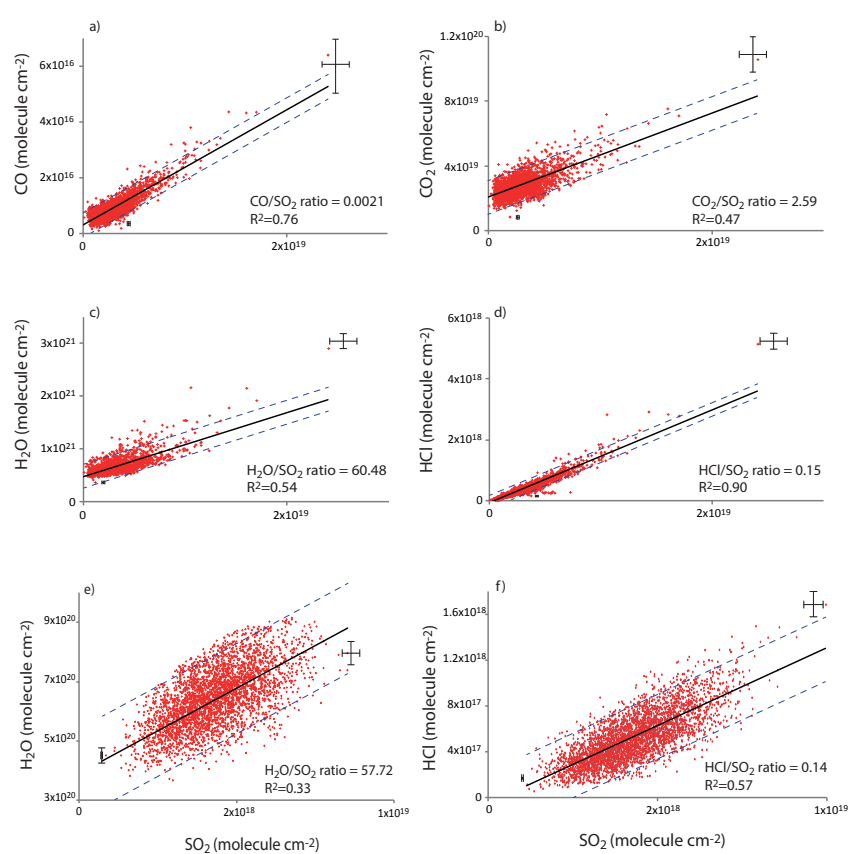

Figure 5. Scatter plots showing column amounts of each volcanic gas species vs. $\mathrm{SO}_{2}$. The upper four scatter plots show data acquired on 26 March 2013 sampling of the Turrialba mixed plume, directly south of the 2010 vent using an IR lamp as source and a $35 \mathrm{~m}$ path length. (a) $\mathrm{CO}$, (b) $\mathrm{CO}_{2}$, (c) $\mathrm{H}_{2} \mathrm{O}$ and (d) $\mathrm{HCl}$. The lower three scatter plots show data acquired on 25 March 2013 sampling the 2012 vent using incandescence from the vent as the IR source and a $350 \mathrm{~m}$ path length. (e) $\mathrm{H}_{2} \mathrm{O}$ and (f) $\mathrm{HCl}$. The $y$-axis offsets seen in (b), (e), (c) and (g) represent the atmospheric background column amounts of $\mathrm{CO}_{2}$ and $\mathrm{H}_{2} \mathrm{O}$ respectively. Dashed lines show prediction bands at $95 \%$ confidence level.

\section{Discussion}

\subsection{Gas flux}

Few measurements of $\mathrm{SO}_{2}$ emissions from Turrialba have been published so far. Martini et al. (2010) reported $\mathrm{SO}_{2}$ fluxes increasing from 0 to $\sim 10 \mathrm{~kg} \mathrm{~s}^{-1}$ from 2002 to 2008 .
Campion et al. (2012) reported $\mathrm{SO}_{2}$ fluxes between $<5$ and $9 \mathrm{~kg} \mathrm{~s}^{-1}$ between September and October 2009, i.e. before the 5 January 2010 eruption, followed by $\mathrm{SO}_{2}$ fluxes of up to $58 \mathrm{~kg} \mathrm{~s}^{-1}$ directly after the eruption, decreasing linearly with time down to $18 \mathrm{~kg} \mathrm{~s}^{-1}$ by January 2011 . Conde et al. (2013) reported $\mathrm{SO}_{2}$ fluxes intermittently for the period 2008 to 2012 using stations from the Novac network. The high uncertainty on their reported data set (with daily variations in $\mathrm{SO}_{2}$ flux spanning up to 3 orders of magnitude and standard deviations similar or larger than the reported values) makes it unideal, however, for comparison purposes. Conde et al. (2014) reported $\mathrm{SO}_{2}$ fluxes between 8 and $11 \mathrm{~kg} \mathrm{~s}^{-1}$ a week prior to our investigation. The average $\mathrm{SO}_{2}$ emission rate data for 3 days of measurements in March 2013 is $5.2 \pm 1.9 \mathrm{~kg} \mathrm{~s}^{-1}$ (equivalent to $446 \pm 162 \mathrm{t} \mathrm{d}^{-1}$ ). This is comparable to the lowest values recorded by previous investigations but indicates the sustained emission of a significant amount of sulfur to the atmosphere from the volcano. The fluxes of other species $\left(\mathrm{CO}_{2}\right.$ excluded, Table 2$)$ are the first such measurements to be reported since the opening of the 2010 and 2012 vents. Fluxes of $\mathrm{H}_{2} \mathrm{O}$ and $\mathrm{CO}_{2}$ are about 5 times lower and $\mathrm{HCl}$ flux is 20 times lower than the flux measured in nearby Masaya Volcano in 1998-1999 (Nicaragua; Burton et al., 2000).

\subsection{Gas composition}

While the multi-gas instrument deployed directly south of the 2010 vent records a $\mathrm{CO}_{2} / \mathrm{SO}_{2}$ molar ratio of 1.76 , the FTIR spectrometer, located a few metres to the east, yields a $\mathrm{CO}_{2} / \mathrm{SO}_{2}$ molar ratio of 2.59 . This discrepancy can be fully attributed to unequal degrees of contribution from the northern fumarolic field. Indeed the multi-gas instrument, located slightly further to the west compared to the FTIR-lamp setup is likely to be more affected by the fumaroles' emissions. A possible hint of this contamination can be seen in Fig. $4 \mathrm{a}$ and to a lesser extent in Fig. 4c, where two dissimilar components with differing $\mathrm{CO}_{2} / \mathrm{SO}_{2}$ ratios can be observed. Future field campaigns should try to avoid this issue by deploying these instruments further to the east. We note that the $\mathrm{CO}_{2} / \mathrm{SO}_{2}$ 
Table 3. Gas emission composition (in mol\%) and molar ratio from several arc volcanoes. Data from Turrialba (this study), Villarrica (Sawyer et al., 2011), Poas (Symonds et al., 1994), Momotombo (Menyailov et al., 1986), Masaya (Martin et al., 2010), Soufriere Hills (Hammouya et al., 1998), Mt St Helens (Gerlach and Casadevall, 1986), Kudryavy (Taran et al., 1995), Usu (Symonds et al., 1994), Showa-shinzan (Symonds et al., 1996), Satsuma Iwo Jima (Shinohara et al., 1993) and Merapi (Le Guern et al., 1982).

\begin{tabular}{|c|c|c|c|c|c|c|c|c|c|c|c|}
\hline \multirow[t]{2}{*}{ Arc volcanoes } & \multirow[t]{2}{*}{ Magma } & \multirow[t]{2}{*}{ Temperature $\left({ }^{\circ} \mathrm{C}\right)$} & \multicolumn{6}{|c|}{ Plume composition (mol\%) } & \multicolumn{3}{|c|}{ Molar ratio } \\
\hline & & & $\mathrm{H}_{2} \mathrm{O}$ & $\mathrm{CO}_{2}$ & $\mathrm{SO}_{2}$ & $\mathrm{H}_{2} \mathrm{~S}$ & $\mathrm{HCl}$ & $\mathrm{HF}$ & $\mathrm{H}_{2} \mathrm{O} / \mathrm{CO}_{2}$ & $\mathrm{SO}_{2} / \mathrm{HCl}$ & $\mathrm{CO}_{2} / \mathrm{SO}_{2}$ \\
\hline Turrialba (2013) & Basaltic andesite & $>800$ & 94.16 & 4.03 & 1.56 & - & 0.2 & - & 23.4 & 7.8 & 2.6 \\
\hline Villarrica (2009) & Basaltic andesite & $\mathrm{nd}^{*}$ & 90.54 & 5.69 & 2.59 & $<0.01$ & 0.87 & 0.3 & 15.9 & 3.0 & 2.2 \\
\hline Poas (1981) & Basaltic andesite & 1045 & 96.69 & 1 & 1.46 & 0.01 & 0.75 & 0.09 & 96.7 & 1.9 & 0.7 \\
\hline Momotombo (1985) & Basalt & 860 & 92.93 & 4.61 & 0.88 & 0.98 & 0.59 & 0.02 & 20.2 & 1.5 & 5.2 \\
\hline Masaya (2009) & Basalt & $\mathrm{nd}^{*}$ & 93.6 & 4.01 & 1.49 & - & 0.74 & 0.17 & 23.3 & 2.0 & 2.7 \\
\hline Soufriere Hills (1996) & Andesite & 720 & 95.9 & 2 & 0.36 & 0.03 & 1.72 & - & 48.0 & 0.2 & 5.6 \\
\hline Mt St Helens (1980) & Dacite & 802 & 92.42 & 7.01 & 0.21 & 0.36 & - & - & 13.2 & - & 33.4 \\
\hline Kudryavy (1991) & Basaltic andesite & 910 & 94.7 & 2.4 & 1.56 & 0.51 & 0.75 & 0.08 & 39.5 & 2.1 & 1.5 \\
\hline Usu (1979) & Dacite & 676 & 96.4 & 2.65 & 0.22 & 0.54 & 0.16 & 0.03 & 36.4 & 1.4 & 12.0 \\
\hline Showa-shinzan (1957) & Dacite & 791 & 99.54 & 0.39 & 0.02 & 0.001 & 0.05 & 0.02 & 255.2 & 0.4 & 19.5 \\
\hline Satsuma Iwo Jima (1990) & Rhyolite & 877 & 97.97 & 0.32 & 0.92 & 0.07 & 0.68 & 0.03 & 306.2 & 1.4 & 0.3 \\
\hline Merapi (1979) & Andesite & 915 & 89.91 & 7.16 & 1.16 & 1.13 & 0.6 & 0.04 & 12.6 & 1.9 & 6.2 \\
\hline
\end{tabular}

* nd: not determined.

molar ratios we obtained are within error of the one reported by Conde et al. (2014) $\left(\mathrm{CO}_{2} / \mathrm{SO}_{2}\right.$ molar ratio of 1.96-2.98) during their investigation earlier in the same month.

The resemblance in chemistry, with near-similar $\mathrm{H}_{2} \mathrm{O} / \mathrm{SO}_{2}$ and $\mathrm{HCl} / \mathrm{SO}_{2}$ molar ratio (Table 2) between the mixed plume (dominated by degassing from the 2010 vent) and the 2012 vent suggests a common magmatic source. This has been made apparent by the May 2013 eruption, in which both vents emitted ash (Fig. 8b). Table 3 compares the mixed plume chemistry from Turrialba to that of other arc volcanoes. The Turrialba plume chemistry most closely resembles that of the Nicaraguan volcanoes (Momotombo and Masaya), especially Masaya. The $\mathrm{SO}_{2} / \mathrm{HCl}$ molar ratio is much higher than that measured at other arc volcanoes presented here ( 7.8 compared to an average of 1.5) and is closer to volcanoes such as Etna and Surtsey (10 and 6.2 respectively; Allard et al., 2005; Gerlach, 1980).

\subsubsection{Oxygen fugacity}

The oxygen fugacity of the degassing magma can be estimated using the measured $\mathrm{CO}_{2} / \mathrm{CO}$ molar ratio of 1334 from the mixed plume based on the reaction

$\mathrm{CO}+1 / 2 \mathrm{O}_{2}=\mathrm{CO}_{2}$

At atmospheric pressure, the fugacity of a gas is equal to its partial pressure (assuming ideal behaviour, which is reasonable for atmospheric pressure) and the oxygen fugacity can be calculated as

$f_{\mathrm{O}_{2}}=\left(K \frac{x_{\mathrm{CO}_{2}}}{x_{\mathrm{CO}}}\right)^{2}$,

where $x_{i}$ the mole fraction of the $i$ th species and $K$ is the equilibrium constant for Eq. (4) and is related to the change

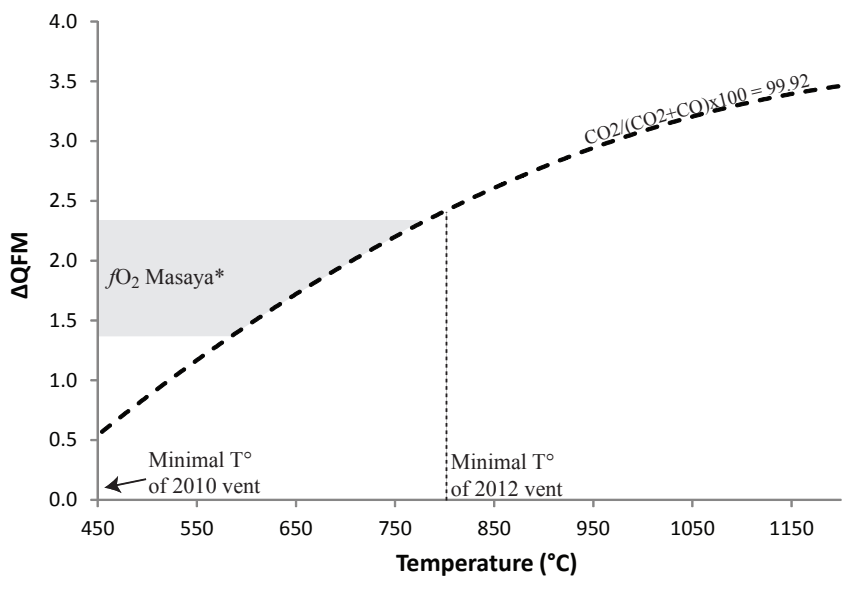

Figure 6. Computed relationship between equilibrium temperature and oxygen fugacity (expressed as deviation from the quartzfayalite-magnetite (QFM) buffer) for the measured $\mathrm{CO}_{2} / \mathrm{CO}$ ratio in the gas emissions from the mixed plume. * : range of $f \mathrm{O}_{2}$ for Masaya Volcano measured by de Moor et al. (2013) in matrix glass from basaltic scoria.

in Gibbs' free energy via

$K=\exp (-\Delta G / R T)$,

where $R$ is the gas constant and $T$ the temperature. The change in Gibbs' free energy $(\Delta G)$ can be computed from the thermochemical JANAF tables for a large range of temperatures. Since the temperature of the magma is unknown, we computed the oxygen fugacity corresponding to a range of possible equilibrium temperatures (Fig. 6). Using a temperature of $800^{\circ} \mathrm{C}$ (the minimum measured at the 2012 vent) as equilibrium temperature yields an $f^{\mathrm{O}_{2}}$ value of $2.4 \log$ units above the quartz-fayalite-magnetite (QFM) buffer. If higher equilibrium temperatures of $900-1000{ }^{\circ} \mathrm{C}$ are used (consistent with the suspected andesite to basaltic-andesite 


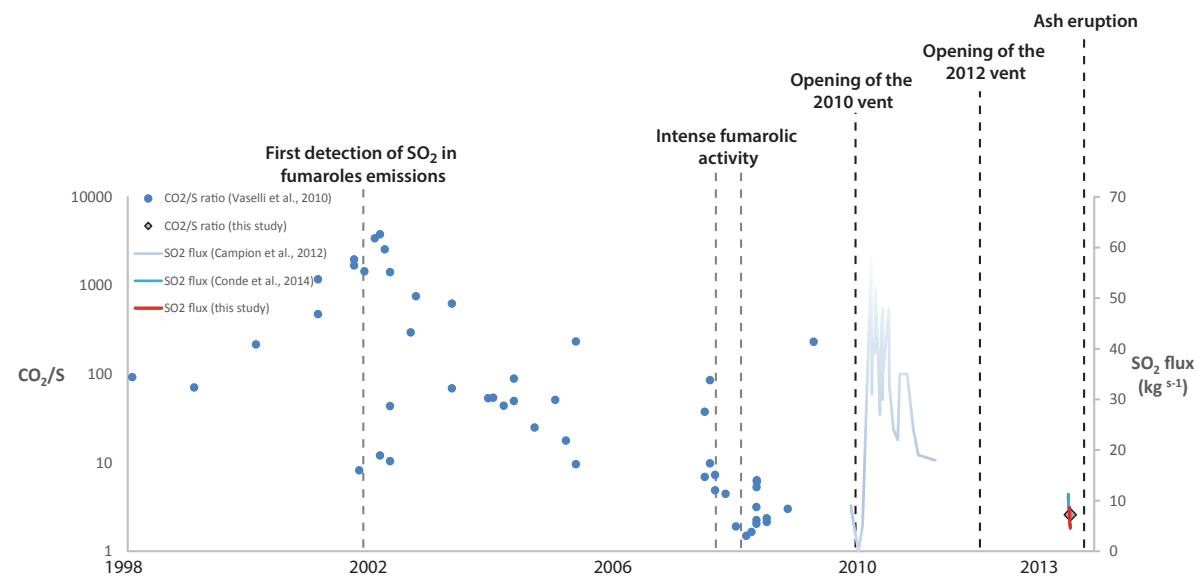

Figure 7. Time series showing the observed evolution of gas emissions in terms of $\mathrm{S} / \mathrm{CO}_{2}$ ratio and $\mathrm{SO}_{2}$ flux from 1998 to 2013 using data from Vaselli et al. (2010), Campion et al. (2012) and this study. Important events such as vent openings during phreatic eruptions are noted.

composition of the Turrialba magma), then $f \mathrm{O}_{2}$ values of 2.8-3.1 log units above the QFM buffer are obtained. In the temperature range considered, using the measured $\mathrm{H}_{2} \mathrm{O} / \mathrm{H}_{2}$ ratio would yield $f \mathrm{O}_{2}$ estimates about $4 \log$ units above the QFM buffer. Because the $\mathrm{H}_{2} \mathrm{O} / \mathrm{H}_{2}$ ratio is obtained using the multi-gas instrument, which as mentioned above shows a greater amount of contamination from the northern fumarolic field and since non-magmatic $\mathrm{H}_{2} \mathrm{O}$ cannot be excluded, we regard the $f \mathrm{O}_{2}$ estimate from the $\mathrm{CO}_{2} / \mathrm{CO}$ ratio as more robust. The oxidised $f \mathrm{O}_{2}$ measured in the gas emissions corresponds to equilibrium conditions with the magma at shallow level and is fairly typical, although slightly high, for arc volcanoes. At Masaya Volcano, the matrix glass from basaltic scoria record close yet slightly more reduced conditions at $1.4-2.3 \pm 0.2 \log$ units above the QFM buffer (de Moor et al., 2013). Using the $f \mathrm{O}_{2}$ values for Masaya as a proxy to that of Turrialba would yield an equilibrium temperature of $\sim 600$ to $800^{\circ} \mathrm{C}$ for the Turrialba system. As of now the system remains underdetermined, but the $f \mathrm{O}_{2}$ of the magma can be constrained to 1.5-3 log units above the QFM buffer with reasonable confidence.

\subsection{Current state of the degassing}

Vaselli et al. (2010) reported substantial changes in gas composition of fumaroles in the summit area from 1998 to 2008 with the detection of $\mathrm{SO}_{2}$ in 2002 and a constant change in gas chemistry (increasing $\mathrm{S} / \mathrm{CO}_{2}$ and $(\mathrm{HF}+\mathrm{HCl}) / \mathrm{CO}_{2}$ ratio) since then. They interpreted this change from lowtemperature hydrothermal-dominated to high-temperature magmatic-dominated chemistry to be related to a cyclic evolution of the hydrothermal system. Since then the 2010 vent opened, releasing $1 \pm 0.3 \mathrm{Tg}$ of $\mathrm{SO}_{2}$ from January 2010 to January 2011 (Campion et al., 2012). Subsequently the 2012 vent opened up and in May 2013 both vents erupted ash (Fig. 8b). The chronology of events and the evolution of gas emission rates and chemistry are summarised in Fig. 7.

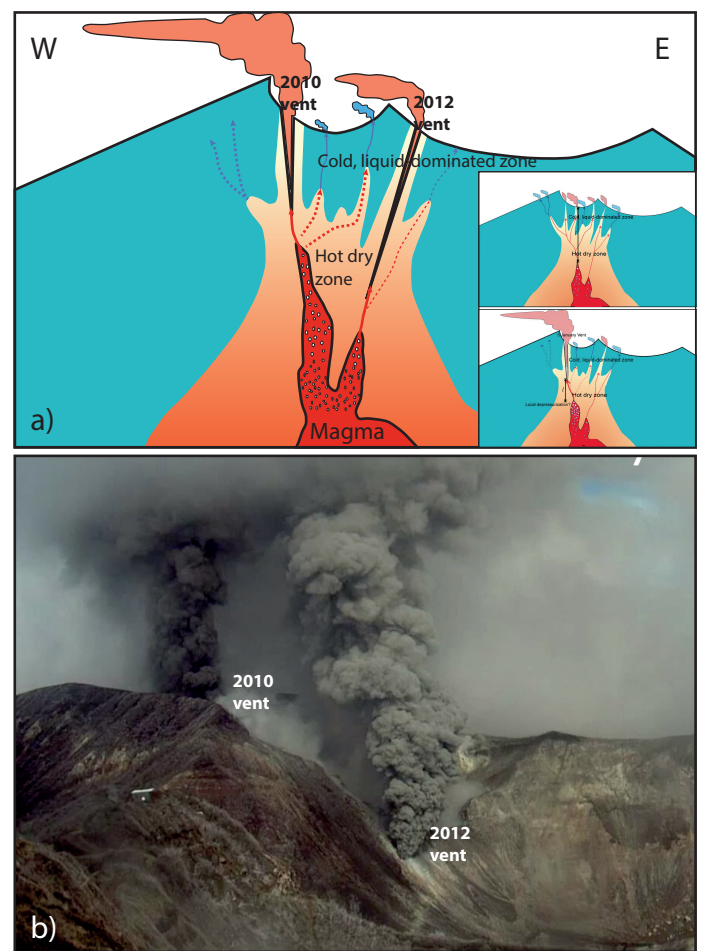

Figure 8. (a) Schematic cross-sectional representation of the summit area of Turrialba at the time of writing. The figure is drawn after the style of Fig. 7 in Campion et al. (2012) (reproduced as inset) showing the progression of the "hot dry zone" since the opening of the 2012 vent. The figure also represents the 2012 vent linked at a slightly deeper level than the 2010 vent as to explain the difference in gas ratios (see text). (b) Photograph from the Turrialba webcam taken on 21 May 2013 showing the most recent ash eruption, in which both vents erupted simultaneously.

From Fig. 7 it appears that the plume chemistry we measured (in terms of $\mathrm{S} / \mathrm{CO}_{2}$, but this is also true in terms of $(\mathrm{HF}+\mathrm{HCl}) / \mathrm{CO}_{2}$ ratio $)$ is similar to that recorded by Vaselli 
et al. (2010) during the intense fumarolic activity of late 2007 to 2008. The $\mathrm{SO}_{2}$ fluxes measured in March 2013 are similar to that measured by Campion et al. (2012) a few months prior to the 2010 phreatic eruption, which is interesting when considering that the 2013 eruption occurred 2 months after our measurements. Although the current data set is too disparate for conclusions to be made with any confidence, this last point does hint of a recurring process. A conceivable scenario is that low $\mathrm{SO}_{2}$ flux is indicative of a decrease in permeability in the upper part of the edifice, leading periodically to small-scale eruptions (with or without the opening of a new vent) following pressure build-up at shallow levels.

The increasing frequency of ash eruptions, the decreasing activity of low-temperature fumaroles since the opening of the 2010 and 2012 vents, the elevated $\left(400\right.$ and $750{ }^{\circ} \mathrm{C}$ respectively) temperatures they show, and the very oxidised gas signature all point towards (in accordance to Campion et al., 2012, and Vaselli et al., 2010) a progressive drying-out of the hydrothermal system and degassing that is controlled by near open-vent processes with limited to negligible interaction with the hydrothermal system. This scenario is depicted in schematic form in Fig. 8a, intentionally drawn in the same style as Fig. 7 in Campion et al. (2012) to show the evolution of the system since their investigation in 2010-2011.

\section{Conclusions}

We measured the composition and flux of gases emitted from Turrialba Volcano in March 2013 using a scanning ultraviolet spectrometer, FTIR spectroscopy and multi-gas sensors. The compositions measured using FTIR are largely consistent with those measured with the multi-gas instrument, and discrepancies may be explained by differing amounts of contamination from fumaroles. The gas composition reflects magmatic degassing with a limited contribution from hydrothermal sources, suggesting near completion of the progressive drying-up of the hydrothermal system in the summit region of Turrialba Volcano or isolation of these main vents from the hydrothermal system. FTIR measurements of the gas emissions from the two main vents reveal only a minor difference in their chemistry. Repeated gas monitoring campaigns of the sort presented here are encouraged in order to capture the future evolution of the state of unrest at Turrialba.

\section{The Supplement related to this article is available online at doi:10.5194/se-14-1341-2014-supplement.}

Acknowledgements. This research was supported by the Royal Geographical Society (with IBG) with a Geographical Fieldwork Grant. Y. Moussallam and N. Peters were additionally supported by the Philip Lake funds from the Department of Geography, University of Cambridge. Y. Moussallam acknowledges a research grant from Mazamas and support through ERC project \#279790. We thank the NERC Field Spectroscopy Facility for the loan of their infrared spectrometer. A. Aiuppa acknowledges support through ERC grant no. 305377 (BRIDGE). We are grateful to Kayla Iacovino and Gino González-Ilama for help in the field. Furthermore, we are grateful to the Robin Campion and the three anonymous referees of the manuscript for their beneficial comments.

Edited by: A. Longo

\section{References}

Aiuppa, A., Federico, C., Giudice, G., Gurrieri, S., and Valenza, M.: Hydrothermal buffering of the $\mathrm{SO}_{2} / \mathrm{H}_{2} \mathrm{~S}$ ratio in volcanic gases: Evidence from La Fossa Crater fumarolic field, Vulcano Island, Geophys. Res. Lett., 33, L21315, doi:10.1029/2006GL027730, 2006.

Aiuppa, A., Shinohara, H., Tamburello, G., Giudice, G., Liuzzo, M., and Moretti, R.: Hydrogen in the gas plume of an openvent volcano, Mount Etna, Italy, J. Geophys. Res., 116, B10204, doi:10.1029/2011JB008461, 2011.

Allard, P., Burton, M., and Muré, F.: Spectroscopic evidence for a lava fountain driven by previously accumulated magmatic gas, Nature, 433, 407-410, doi:10.1038/nature03246, 2005.

Avoscan: A code for controlling AvoScanners: http://code.google. com/p/avoscan/, last access: June 2013.

Boichu, M., Oppenheimer, C., Tsanev, V., and Kyle, P. .: High temporal resolution $\mathrm{SO} 2$ flux measurements at Erebus volcano, Antarctica, J. Volcanol Geoth. Res., 190, 325-336, doi:10.1016/j.jvolgeores.2009.11.020, 2010.

Burrows, J. P., Richter, A., Dehn, A., Deters, B., Himmelmann, S., Voigt, S., and Orphal, J.: Atmospheric remote-sensing reference data from GOME - 2. Temperature-dependent absorbtion cross sections of $\mathrm{O}_{3}$ in the 231-794 nm range, Journal of Quantitative Spectroscopy and Radiative Transfer, 61, 509-517, doi:10.1016/S0022-4073(98)00037-5, 1999.

Burton, M., Allard, P., Mure, F., and La Spina, A.: Magmatic Gas Composition Reveals the Source Depth of SlugDriven Strombolian Explosive Activity, Science, 317, 227-230, doi:10.1126/science.1141900, 2007.

Burton, M. R., Oppenheimer, C., Horrocks, L. A., and Francis, P. W.: Remote sensing of $\mathrm{CO}_{2}$ and $\mathrm{H}_{2} \mathrm{O}$ emission rates from Masaya volcano, Nicaragua, Geology, 28, 915-918, doi:10.1130/0091-7613(2000)28<915:RSOCAH >2.0.CO;2, 2000.

Campion, R., Martinez-Cruz, M., Lecocq, T., Caudron, C., Pacheco, J., Pinardi, G., Hermans, C., Carn, S. and Bernard, A.: Spaceand ground-based measurements of sulphur dioxide emissions from Turrialba Volcano (Costa Rica), B. Volcanol., 74, 17571770, doi:10.1007/s00445-012-0631-z, 2012.

Chance, K. and Kurucz, R. L.: An improved high-resolution solar reference spectrum for earth's atmosphere measurements in the ultraviolet, visible, and near infrared, J. Quant. Spectrosc. Ra., 111, 1289-1295, 2010.

Conde, V., Bredemeyer, S., Duarte, E., Pachevo, J. F., Miranda, S., Galle, B., and Hansteen, T. H.: $\mathrm{SO}_{2}$ degassing from Turrialba Volcano linked to seismic signatures during the period 2008- 
2012, Int. J. Earth Sci., 103, 1983-1998, doi:10.1007/s00531013-0958-5, 2013.

Conde, V., Robidoux, P., Avard, G., Galle, B., Aiuppa, A., Muñoz, A., and Giudice, G.: Measurements of volcanic $\mathrm{SO}_{2}$ and $\mathrm{CO}_{2}$ fluxes by combined DOAS, Multi-GAS and FTIR observations: a case study from Turrialba and Telica volcanoes, Int. J. Earth Sci., 103, 2335-2347, doi:10.1007/s00531-014-1040-7, 2014.

de Moor, J. M., Fischer, T. P., Sharp, Z. D., King, P. L., Wilke, M., Botcharnikov, R. E., Cottrell, E., Zelenski, M., Marty, B., Klimm, K., Rivard, C., Ayalew, D., Ramirez, C., and Kelley, K. A.: Sulfur degassing at Erta Ale (Ethiopia) and Masaya (Nicaragua) volcanoes: Implications for degassing processes and oxygen fugacities of basaltic systems, Geochem. Geophy. Geosy., 14, 4076-4108, doi:10.1002/ggge.20255, 2013.

Galle, B., Oppenheimer, C., Geyer, A., McGonigle, A. J., Edmonds, M., and Horrocks, L.: A miniaturised ultraviolet spectrometer for remote sensing of $\mathrm{SO}_{2}$ fluxes: a new tool for volcano surveillance, J. Volcanol. Geoth. Res., 119, 241-254, 2003.

Gerlach, T. M.: Evaluation of volcanic gas analysis from surtsey volcano, iceland 1964-1967, J. Volcanol. Geoth. Res., 8, 191198, doi:10.1016/0377-0273(80)90104-3, 1980.

Gerlach, T. M. and Casadevall, T. J.: Evaluation of gas data from high-temperature fumaroles at Mount St. Helens, 19801982, J. Volcanol. Geoth. Res., 28, 107-140, doi:10.1016/03770273(86)90008-9, 1986.

González, G., Mora-Amador, R., Ramírez, C., Rouwet, D., Picado, C., and Mora, R.: Actividad Histórica y Análisis de la Amenaza del Volcán Turrialba, Costa Rica, Revista Geologica de America Central, in press, 2014 (in Spanish).

Hammouya, G., Allard, P., Jean-Baptiste, P., Parello, F., Semet, M. P., and Young, S. R.: Pre- and syn-eruptive geochemistry of volcanic gases from Soufriere Hills of Montserrat, West Indies, Geophys. Res. Lett., 25, 3685-3688, doi:10.1029/98GL02321, 1998.

Horrocks, L. A., Oppenheimer, C., Burton, M. R., Duffell, H. J., Davies, N. M., Martin, N. A. and Bell, W.: Open-path Fourier transform infrared spectroscopy of $\mathrm{SO}_{2}$ : An empirical error budget analysis, with implications for volcano monitoring, J. Geophys. Res., 106, 27647, doi:10.1029/2001JD000343, 2001.

Le Guern, F., Gerlach, T. M., and Nohl, A.: Field gas chromatograph analyses of gases from a glowing dome at Merapi volcano, Java, Indonesia, 1977, 1978, 1979, J. Volcanol. Geoth. Res., 14, 223245, doi:10.1016/0377-0273(82)90063-4, 1982.

Martin, R. S., Sawyer, G. M., Spampinato, L., Salerno, G. G., Ramirez, C., Ilyinskaya, E., Witt, M. L. I., Mather, T. A., Watson, I. M., Phillips, J. C., and Oppenheimer, C.: A total volatile inventory for Masaya Volcano, Nicaragua, J. Geophys. Res., 115, B09215, doi:10.1029/2010JB007480, 2010.

Martini, F., Tassi, F., Vaselli, O., Del Potro, R., Martinez, M., del Laat, R. V., and Fernandez, E.: Geophysical, geochemical and geodetical signals of reawakening at Turrialba volcano (Costa Rica) after almost 150 years of quiescence, J. Volcanol Geoth. Res., 198, 416-432, doi:10.1016/j.jvolgeores.2010.09.021, 2010.

Menyailov, I. A., Nikitina, L. P., Shapar, V. N., and Pilipenko, V. P.: Temperature increase and chemical change of fumarolic gases at Momotombo Volcano, Nicaragua, in 1982-1985: Are these indicators of a possible eruption?, J. Geophys. Res., 91, 12199_ 12214, doi:10.1029/JB091iB12p12199, 1986.
Oppenheimer, C.: Ultraviolet Sensing of Volcanic Sulfur Emissions, Elements, 6, 87-92, doi:10.2113/gselements.6.2.87, 2010.

OVSICORI: Actividad del volcán Turrialba entre el 4 y el 8 de enero del 2010, Observatorio Vulcanológico y Sismológico de Costa Rica, Universidad Nacional, Heredia, Costa Rica, Report, 2010 (in Spanish).

OVSICORI: Volcán Turrialba: Apertura de una nueva boca fumarólica en el flanco sureste del Cráter Oeste el 12 de enero 2012, Observatorio Vulcanológico y Sismológico de Costa Rica, Universidad Nacional, Heredia, Costa Rica, Report, 2010 (in Spanish)

Platt, U. and Stutz, J.: Differential absorption spectroscopy, in Differential Optical Absorption Spectroscopy, Springer Berlin Heidelberg, Berlin, Heidelberg, 135-174, 2008.

Reagan, M., Duarte, E., Soto, G. J., and Fernandez, E.: The eruptive history of Turrialba volcano, Costa Rica, and potential hazards from future eruptions, in: Volcanic Hazards in Central America, vol. 412, edited by: Rose, W. I., Bluth, G. J. S., Carr, M. J., Ewert, J. W., Patino, L. C., and Vallance, J. W., Geological Soc Amer Inc, Boulder, 235-257, 2006.

Red Sismológica Nacional: Informe Sobre la Actividad de los Volcanes Activos de Costa Rica Mayo, Report, 2013 (in Spanish).

Sawyer, G. M., Salerno, G. G., Le Blond, J. S., Martin, R. S., Spampinato, L., Roberts, T. J., Mather, T. A., Witt, M. L. I., Tsanev, V. I., and Oppenheimer, C.: Gas and aerosol emissions from Villarrica volcano, Chile, J. Volcanol. Geoth. Res., 203, 6275, doi:10.1016/j.jvolgeores.2011.04.003, 2011.

Shinohara, H., Giggenbach, W. F., Kazahaya, K., and Hedenquist, J. W.: Geochemistry of volcanic gases and hot springs of Satsuma-Iwojima, Japan: following Matsuo, Geochem. J., 27, 271-285, 1993.

Surono, P. J., Pallister, J., Boichu, M., Buongiorno, M. F., Budisantoso, A., Costa, F., Andreastuti, S., Prata, F., Schneider, D., Clarisse, L., Humaida, H., Sumarti, S., Bignami, C., Griswold, J., Carn, S., Oppenheimer, C., and Lavigne, F.: The 2010 explosive eruption of Java's Merapi volcano - A "100year" event, J. Volcanol. Geoth. Res., 241-242, 121-135, doi:10.1016/j.jvolgeores.2012.06.018, 2012.

Symonds, R. B., Rose, W. I., Bluth, G. J. S., and Gerlach, T. M.: Volcanic-gas studies; methods, results, and applications, Rev. Mineral. Geochem., 30, 1-66, 1994.

Symonds, R. B., Mizutani, Y., and Briggs, P. H.: Long-term geochemical surveillance of fumaroles at Showa-Shinzan dome, Usu volcano, Japan, J. Volcanol. Geoth. Res., 73, 177-211, doi:10.1016/0377-0273(96)00029-7, 1996.

Taran, Y. A., Hedenquist, J. W., Korzhinsky, M. A., Tkachenko, S. I., and Shmulovich, K. I.: Geochemistry of magmatic gases from Kudryavy volcano, Iturup, Kuril Islands, Geochimi. Cosmochim. Ac., 59, 1749-1761, doi:10.1016/00167037(95)00079-F, 1995.

Vandaele, A. C., Simon, P. C., Guilmot, J. M., Carleer, M., and Colin, R.: $\mathrm{SO}_{2}$ absorption cross section measurement in the UV using a Fourier transform spectrometer, J. Geophys. Res., 99, 25599-25605, doi:10.1029/94JD02187, 1994.

Vaselli, O., Tassi, F., Duarte, E., Fernandez, E., Poreda, R. J., and Huertas, A. D.: Evolution of fluid geochemistry at the Turrialba volcano (Costa Rica) from 1998 to 2008, B. Volcanol., 72, 397410, doi:10.1007/s00445-009-0332-4, 2010. 